\title{
Assessment of Knowledge and Practices of Health Team Toward Radiation Hazards and it's Safety Measures at Assuit University Hospitals
}

\author{
Manal S. Ahmed, Hoda D. Fahmy, Soad A. Sharkawy \& Amr F. Maurad. \\ Nursing Specialist in the Technical Secondary of Nursing, for girls at Assuit city, Egypt. \\ Professor of Community Health Nursing Faculty of Nursing, Assuit University, Egypt. \\ Assistant Professor of Community Health Nursing, Faculty of Nursing- Assuit University, Egypt. \\ Assistant Professor of Radio diagnostic of Oncology, South Egypt, Cancer Institute, Egypt.
}

\begin{abstract}
Radiation is a threat to health in work place and in general environment. Workers in radiation therapy department are exposed to a variety of occupational hazards. Health care and safety measures compliance may decrease the health sequences of hazards occurrence. The study aimed to assess knowledge and practice of health care team about radiation hazards and it's safety measures. A descriptive design was used in this study. It was conducted at the Main Assuit University hospital and South Egypt Cancer Institute. A convenient sample (300) from heath team workers from the previous setting. Two tools was used (1) Self administrative and interview questionnaire. (2) Health team observation check list. Results: There were significant statistical differences in relation between health team knowledge and their performance. The study concluded that health team had poor knowledge about radiation hazards and most of them had satisfactory practice about safety measures. It recommend that hospitals must be provide radiation departments with adequate personal protective equipment to reduce exposure of health system from radiation hazards and establish plans for periodical safety training courses and educational programs for health team members in radiation setting to help in improving their practice and update their knowledge.
\end{abstract}

\section{Keywords: Radiation.Safety measures. Knowledge \&Practice.}

\section{Introduction}

Since the end of the 19th Century, man has learned to use radiation for many beneficial purposes. Today, many sources of radiation, such as $\mathrm{x}$-ray machines, linear accelerators and radionuclide are used in clinical and research applications. Such beneficial uses may at times create potentially hazardous situations for personnel who work within the hospital (Radiation Protection Guidance, 2010).

Radiation is generated by common sources like the sun, radioactive materials and electronic devices. It can be classified as ionizing and non-ionizing. Ionizing radiation is also produced by certain human activities, such as medicine and industry, and may result from accidents in nuclear facilities and nuclear bomb explosions. It includes $\mathrm{X}$-rays and gamma rays under any condition; also it includes atomic particles and non-ionizing radiation under certain conditions (Amirzadeh, 2007).

Ionizing radiation is energy or particles (protons, electrons or neutrons) produced by unstable atoms of radioactive materials .It is present in the environment ,as a result of both naturally occurring radioactive minerals and cosmic radiation arriving from outer space. Although ionizing radiation is used for beneficial purposes in medicine and industry. IT can present health hazards if it's not properly monitored and controlled $\left(\mathbf{W H O}_{\mathbf{a}}, \mathbf{2 0 1 4}^{2}\right.$ ).
Non ionizing radiation is the term given to radiation in the part of the electromagnetic spectrum where there is in insufficient energy to cause ionizing but it has sufficient energy only for excitation. It includes electric and magnetic fields, radio waves, microwaves, infrared ultraviolet and visible radiation $\left(\mathrm{WHO}_{\mathrm{b}}, \mathbf{2 0 1 4}\right)$.

Radiation therapy employs ionizing radiation to treat diseases. Although it can be used to treat specific benign diseases, such as hyperthyroidism and benign brain tumours, it is most commonly used to treat malignant tumours. Although caners are often considered a disease of aging, with the majority of cases $(76 \%)$ were diagnosed as cancer over the age of 55years, it occurs in people of all ages. An estimated number of cancer $1.399,780$ persons were diagnosed in2006 excluding skin cancer (more than 1 million are diagnosed annually) in USA (Gates et al., 2008).

To protect the works in radiation therapy departments from radiation hazards should wear monitoring devices (e.g a film badge) to measure commutative radiation exposure. On the other hand the workers are protected from radiation by environmental design and rules of activity and location which assure shielding and distance from the radiation source and the walls of therapy room are thick concrete, in addition to personal protective devices such as helmet for head 
protection, goggles for eye protection, and ear plugs for ear protection. Mask for lung protections etc (Mojiri \&Moghimbeigi , 2011).

Occupational radiation protective measures are necessary for all individuals who work in the diagnostic imaging departments. This includes not only technologists and nurses, but also individuals who may be in a radiation environment only occasionally. All of these individuals may be considered radiation workers, depending on their level of exposure and on national regulations. All workers require appropriate monitoring continuously by common personnel dosimeters like film badge .They must also receive education and training appropriate to their jobs and protect by tools and equipment (Rahman, 2008).

The occupational health nurse has special knowledge about understanding of the principles of safety, toxicology, industrial hygiene, epidemiology and environmental health, additionally, special skills in training in safety hazards, disaster planning for military with safety equipment, ability to plan and implement health and educational program. Occupational health nurse are also required to have up to update knowledge of current legal standards that affect the working population (Smith, 2013).

\section{Significance of the study}

Radiation is a threat to health in their work place and in general environment, the extent of danger depends on the dose and type of radiation. Prolonged exposure to radiation can cause skin ulcers, damage to cells, cancer, premature aging, kidney dysfunction, cataracts, and genetic disorders in the children of those cells have been damaged (Wiley, 2008). According to (Cardis et al., 2007) who found that a significant association was seen between radiation dose and all-cause of mortality.

According to (Mohammed et al., 2012) Who found that $20 \%$ of exposed personnel of radiation have history of skin disease, hypotension and suffering from symptoms such as headache, dizziness, and tiredness. There was statistically significant difference in history of illness condition to work such as myocardial infarction, gastritis, eczema, fainting attacks and irregular uterine bleeding among exposed and non- exposed person.

\section{Aim of the study}

\section{Objective of the study}

Assess knowledge and practice of health care team about radiation hazards and it's safety measures.

\section{Research question:-}

- What is the health team know about radiation hazards and it's safety measures?
- What is the current health team practices regarding radiation hazards and it's safety measures?

- Is there relation between health team knowledge about radiation hazards and their practices?

\section{Subjects \& methods}

\section{Research design}

A descriptive research design was used in this study. Setting

This study was conducted at Assuit University hospitals including the target population in the Main Assuit University hospital and South Egypt Cancer Institute. The present study included the following department (Diagnostic radiation, oncology and nuclear medicine department).

\section{Sample}

A convenient sample was used to include all health team at the two previous setting. (224) from Main Assuit University hospital and (76) from South Egypt Cancer Institute. The total sample size was (300) it divided into (5)department; radiologists (32) oncologists (34) nurses (45) technicians (126) and cleaners (63) working in the radiation department (diagnostic radiation, oncology and nuclear medicine department).

Tools of the study

Two tools were used to collect data for this study

Tool I

Self-administrative questionnaire for all health team expect cleaners number (237), and interview questionnaire for cleaners their number (63) and sheet was developed by the researchers to collect information from the participants. It includes two parts:

Part (1)

Included questions regarding Socio demographic characteristics of health team such as name, sex, age, marital status, working department, educational level, years of experience and occupation.

Part (2)

Knowledge of health team regarding to radiation hazards and it's safety measures such as: definition, types, causes, uses, and effect of radiation on cells. Questions about health safety measures of radiation unit, personal protective equipment and types of occupational hazards and the effect of radiation on health, how to protect them-selves from occupational hazards, sources of information, most common diseases associated with radiation . Question related to factors affecting using safety measures such as availability of safety measures, periodical checkup, attending training regarding using personal safety measures, lack of follow up supervision and punishment against un used personal safety measures. 


\section{Scoring system}

A score of 1degree was given for each correct answer and a score of zero was given for an incorrect answer. The score of each item summed-up and then converted into a percent score. Poor knowledge: score less than 50\%, Fair knowledge: if score is from $50-70 \%$ and Good knowledge: if score more than 70\% (Abd Elzaher et al., 2014).

\section{Tool II:}

Observation check list was developed by the researchers to collect data related to performance of health team members regarding to application of radiation safety measures during their work. It Include health team compliance to different types of personal protective equipment usage, such as wearing gloves, gown, suitable mask, head cap, and eye protective glass. Health team compliance to safe work procedure such as time, distance, shielding and hand washing. Work setting compliance to radiation safety policy such as training, health education given to patients before and after procedures Posting, labeling and security such as warning and caution sings displayed at door and equipment. Cleaning as follow standers of infection control.

\section{Scoring system}

Regarding to total scoring for health team practice .A score of 1degree was given for each done and a score of zero was given for not done. The score of each item summed-up and then converted into a percent score. Poor practice: score less than 50\%, fair practice: if score is from $50-70 \%$ and Good practice: if score more

than 70\% (Abd Elzaher et al., 2014) .

Methodology:

- Administrative phase

An official letter approval was obtains from the dean of the Faculty of Nursing at Assuit University was sent to director of the main Assuit University hospital and the dean of South Egypt Cancer Institute. This letter included a brief explanation of the objectives of the study and a permission to carry out this research .

\section{- Pilot Study}

A pilot study was carried out before starting data collection on 30 members of health team in the two setting of radiation department which represent the studied sample in order to test the clarity and applicability of questions and statement, content, feasibility and consistency of the tool to detect any ambiguity in the study tools. The pilot study has also served to estimate the time required to full fill the study tool.

Validity of tool: To evaluate the tool validity. It was reviewed by five experts in nursing sciences.

\section{III- Data collection Phase Ethical considerations}

Written consent taken from director of the place and oral consent should be taken from all members of health team who participate in the study. The purpose of the study was explained for the director and every interviewed member of health team. Members of health team have ethical right to participate or refuse participation in the study; the information that obtained is confidential and used only for the purpose of the study.

\section{Field work}

Data was collected in the period from $21^{\text {st }}$ February, 2015 to $5^{\text {th }}$ July, 2015 The researchers introduce themselves and explain the purpose of the study for the participants. The average of time taken for completing each sheet was around 15-20 minutes depending on the persons' response to questions. The data was collected at Saturday, Sunday, and Monday at morning shift /week. About (3- 6) sheet and observation check list was finished daily. Observation check list done by the researchers themselves to assess radiologist, oncologist, nurse, technician and cleaners performance before, during and after finishing the work toward radiation safety measures on the actual and clinical situation of their work setting.

\section{Statistical analysis}

The collected data were tabulated and analyzed by computer using the "Statistical Package for the Social Sciences" (SPSS) version 16. Descriptive statistics such as frequency, mean, and standard deviation were utilized to analyze data. Relevant statistical tests of significance were used to identify the relations among the study variables. Chi square and correlations were used to compare difference in the distribution of frequencies between different groups. It was considered significant when $\mathrm{p}$ - values were less than 0.05 . And to identify the significance of the relations, associations, and interactions among variables. 


\section{Results:}

Table (1): Distribution of the Studied Sample Regarding to Their Socio Demographic Characteristics at Assuit University Hospitals 2015 ( $\mathbf{N}=300)$.

\begin{tabular}{|c|c|c|}
\hline Variables & No. $(n=300)$ & $\%$ \\
\hline \multicolumn{3}{|l|}{ Age: (years) } \\
\hline$<30$ & 107 & 35.7 \\
\hline $30-40$ & 122 & 40.6 \\
\hline$>40$ & 71 & 23.7 \\
\hline \multicolumn{3}{|l|}{ Sex } \\
\hline Male & 203 & 67.7 \\
\hline Female & 97 & 32.3 \\
\hline \multicolumn{3}{|l|}{ Marital status } \\
\hline Single & 82 & 27.4 \\
\hline Married & 216 & 72.0 \\
\hline Divorced \&Widow & 2 & 0.6 \\
\hline Pregnant now & $\mathrm{N}=69$ & $\%$ \\
\hline Yes & 9 & 13.0 \\
\hline No & 60 & 87.0 \\
\hline \multicolumn{3}{|l|}{ Have children } \\
\hline Yes & 59 & 85.5 \\
\hline No & 10 & 14.5 \\
\hline Years of marriage & $\mathrm{N}=69$ & $\%$ \\
\hline$<5$ years & 27 & 39.2 \\
\hline $5-10$ years & 19 & 27.5 \\
\hline$>10$ years & 23 & 33.3 \\
\hline \multicolumn{3}{|l|}{ Level of education } \\
\hline Illiterate & 20 & 6.7 \\
\hline Basic education & 42 & 14.0 \\
\hline Secondary & 43 & 14.3 \\
\hline Technical Institute & 126 & 42.0 \\
\hline University & 31 & 10.3 \\
\hline Post graduate & 38 & 12.7 \\
\hline
\end{tabular}

Table (2): Distribution of the Studied Sample According to their Working Condition at Assuit University Hospitals $2015(\mathrm{~N}=\mathbf{3 0 0})$.

\begin{tabular}{|c|c|c|}
\hline Variables & No. $(n=300)$ & $\%$ \\
\hline \multicolumn{3}{|l|}{ Work place } \\
\hline Main Assiut University Hospital & 224 & 74.7 \\
\hline South Egypt Assiut Institute & 76 & 25.3 \\
\hline \multicolumn{3}{|l|}{ Department } \\
\hline Diagnostic Radiation & 196 & 65.3 \\
\hline Nuclear Medicine and Oncology Unit & 104 & 34.7 \\
\hline \multicolumn{3}{|l|}{ Occupation } \\
\hline Radiologist & 32 & 10.7 \\
\hline Oncologist & 34 & 11.3 \\
\hline Nurse & 45 & 15.0 \\
\hline Technician & 126 & 42.0 \\
\hline Cleaner & 63 & 21.0 \\
\hline \multicolumn{3}{|l|}{ Years of experience } \\
\hline$<5$ years & 95 & 31.7 \\
\hline $5-<10$ years & 83 & 27.7 \\
\hline $10-<15$ years & 54 & 18.0 \\
\hline$\geq 15$ years & 68 & 22.7 \\
\hline
\end{tabular}

What is the health team know about radiation hazards and it's safety measures? Table $(3,4,5)$ 
Table (3): Knowledge of the Studied Sample About Radiation at Assuit University Hospitals 2015. (N =300).

\begin{tabular}{|l|c|c|}
\hline \multicolumn{1}{|c|}{ Variables } & No. $(\mathbf{n}=\mathbf{3 0 0})$ & \% \\
\hline Definition of radiation & 233 & 77.7 \\
\hline Incorrect & 67 & 22.3 \\
\hline Correct & \multicolumn{2}{|c|}{} \\
\hline Types of radiation & 203 & 67.7 \\
\hline Incorrect & 97 & 32.3 \\
\hline Correct & 12 & 4.0 \\
\hline Causes of radiation pollution & 53 & 17.7 \\
\hline The survey meter is not used correctly & 5 & 1.7 \\
\hline The film bad age is not used correctly & 75 & 25.0 \\
\hline The alarm ratemeter is not used correctly & 155 & 51.7 \\
\hline All of the above & & \\
\hline Don't know & 80 & 26.7 \\
\hline A symptom resulting from an overexposure to radiation & 6 & 2.0 \\
\hline Somatic effects & 43 & 14.3 \\
\hline Biological effects & 2 & 0.7 \\
\hline Latent effects & 143 & 47.7 \\
\hline Genealogy effects & 26 & 8.7 \\
\hline All of the above & \multicolumn{2}{|l|}{} \\
\hline Don't know & \multicolumn{2}{|l|}{} \\
\hline
\end{tabular}

Table (4): Knowledge of the Studied Sample About Radiation Therapy at Assuit University Hospitals 2015. $(\mathbf{N}=\mathbf{3 0 0})$.

\begin{tabular}{|c|c|c|}
\hline Variables & No. $(n=300)$ & $\%$ \\
\hline \multicolumn{3}{|l|}{ Define of radiation therapy } \\
\hline Incorrect & 232 & 77.3 \\
\hline Correct & 68 & 22.7 \\
\hline \multicolumn{3}{|l|}{ Uses of radiation therapy } \\
\hline Incorrect & 27 & 9.0 \\
\hline Correct & 273 & 91.0 \\
\hline \multicolumn{3}{|l|}{ Mechanism of radiation therapy } \\
\hline Incorrect & 85 & 28.3 \\
\hline Correct & 215 & 71.7 \\
\hline \multicolumn{3}{|l|}{ Effect of radiation therapy on cells } \\
\hline Cancer cells only & 75 & 25.0 \\
\hline Healthy cells only & 1 & .3 \\
\hline Cancer\& Healthy cells & 171 & 57.0 \\
\hline Do not know & 53 & 17.7 \\
\hline \multicolumn{3}{|l|}{ Types of radiation therapy } \\
\hline Internal radiation therapy only & 12 & 4.0 \\
\hline External radiation therapy only & 7 & 2.3 \\
\hline All of the above & 210 & 70.0 \\
\hline Do not know & 71 & 23.7 \\
\hline \multicolumn{3}{|c|}{ Factors determine the number and duration of radiation therapy sessions:\# } \\
\hline Type of tumor & 136 & 45.3 \\
\hline Patient's age & 38 & 12.7 \\
\hline Patient's weight & 52 & 17.3 \\
\hline Patient's sex & 12 & 4.0 \\
\hline Don't know & 151 & 50.3 \\
\hline
\end{tabular}




\begin{tabular}{|c|c|c|}
\hline Variables & No. $(n=300)$ & $\%$ \\
\hline \multicolumn{3}{|l|}{ Time of radiation therapy session } \\
\hline Incorrect & 78 & 26.0 \\
\hline Correct & 222 & 74.0 \\
\hline \multicolumn{3}{|c|}{ Special precautions of radiation therapy } \\
\hline Incorrect & 111 & 37.0 \\
\hline Correct & 189 & 63.0 \\
\hline \multicolumn{3}{|c|}{ Radiation used for all types of cancer treatment } \\
\hline Yes & 202 & 67.3 \\
\hline No & 98 & 32.7 \\
\hline
\end{tabular}

\# More than one answers according their responses

Table (5): Knowledge of the Studied Sample About Safety Measures at Assuit University Hospitals 2015. $(\mathbf{N}=\mathbf{3 0 0})$.

\begin{tabular}{|c|c|c|}
\hline Variables & No. $(n=300)$ & $\%$ \\
\hline \multicolumn{3}{|l|}{ Importance of safety tools } \\
\hline Incorrect & 25 & 8.3 \\
\hline Correct & 275 & 91.7 \\
\hline \multicolumn{3}{|c|}{ Knowledge about personal measures for health team:\# } \\
\hline Gloves and suitable shoes & 204 & 68.0 \\
\hline Gown & 131 & 43.7 \\
\hline Apron from lead & 121 & 40.3 \\
\hline Monitoring badges & 103 & 34.3 \\
\hline Mask & 74 & 24.7 \\
\hline Eye protective glass & 68 & 22.7 \\
\hline Head cup & 7 & 2.3 \\
\hline Do not know & 69 & 23.0 \\
\hline \multicolumn{3}{|l|}{ Safety precaution for the unit of radiation } \\
\hline Present & 226 & 75.3 \\
\hline Not present & 74 & 24.7 \\
\hline Safety characteristics for the unit of radiation:\# & $N=226$ & \\
\hline Lead walls and glass & 191 & 84.5 \\
\hline Ground floor easy to clean and not absorb radiation & 135 & 59.7 \\
\hline Barrier & 133 & 58.8 \\
\hline Good ventilation & 88 & 38.9 \\
\hline Warning devices & 50 & 22.1 \\
\hline Monitoring badges & 47 & 20.8 \\
\hline Complete emergency equipment & 4 & 1.8 \\
\hline Special containers for keeping radioactive materials & 2 & 0.9 \\
\hline Do not know & 20 & 8.8 \\
\hline \multicolumn{3}{|l|}{ Safety characteristics for radiation devices } \\
\hline Have the ability to move easily & 192 & 64.0 \\
\hline Have the ability to absorb radiation & 67 & 22.3 \\
\hline Containing soft lighting & 7 & 2.3 \\
\hline Other & 7 & 2.3 \\
\hline Do not know & 27 & 9.0 \\
\hline
\end{tabular}

\# More than one answers according their responses 
What is the current health team practices regarding radiation hazards and it's safety measures? Table (6)

Table (6): Distribution of the Studied Sample According to Radiation Safety Practices at Assuit University Hospitals $2015(\mathbf{N}=300)$

\begin{tabular}{|c|c|c|c|c|}
\hline \multirow{2}{*}{ Variables } & \multicolumn{2}{|c|}{ Done } & \multicolumn{2}{|c|}{ Not done } \\
\hline & No. & $\%$ & No. & $\%$ \\
\hline \multicolumn{5}{|l|}{ Health team compliance to personal protective equipment } \\
\hline Wearing gloves at all time & 159 & 53.0 & 141 & 47.0 \\
\hline Wearing gown at all time & 115 & 38.3 & 185 & 61.7 \\
\hline Wearing suitable mask & 60 & 20.0 & 240 & 80.0 \\
\hline Wearing appropriate monitoring badges & 22 & 7.3 & 278 & 92.7 \\
\hline Wearing head cup & 6 & 2.0 & 294 & 98.0 \\
\hline Wearing eye protective & 10 & 3.3 & 290 & 96.7 \\
\hline \multicolumn{5}{|l|}{ Compliance to safe work procedure } \\
\hline Safe work practice adapted to make appropriate use of time & 221 & 73.7 & 79 & 26.3 \\
\hline Safe work practice with suitable distance & 213 & 71.0 & 87 & 29.0 \\
\hline Safe work practice with shielding & 174 & 58.0 & 126 & 42.0 \\
\hline Regular hand washing after each procedure & 132 & 44.0 & 168 & 56.0 \\
\hline Eye washing & 15 & 5.0 & 285 & 95.0 \\
\hline \multicolumn{5}{|l|}{ Training } \\
\hline Were provided appropriate safety training before starting their work & 22 & 7.3 & 278 & 92.7 \\
\hline Were given regular refresh radiation safety training & 22 & 7.3 & 278 & 92.7 \\
\hline Do report & 22 & 7.3 & 278 & 92.7 \\
\hline Record of training are keeping & 22 & 7.3 & 278 & 92.7 \\
\hline \multicolumn{5}{|l|}{ Health education } \\
\hline Give patient instructions before procedures & 233 & 98.3 & 4 & 1.7 \\
\hline Give patient instructions after procedures & 233 & 98.3 & 4 & 1.7 \\
\hline \multicolumn{5}{|l|}{ Posting, Labeling and Security } \\
\hline Are radiation warning signs displayed at the door & 299 & 99.7 & 1 & .3 \\
\hline Are caution signs grinding equipment & 297 & 99.0 & 3 & 1.0 \\
\hline $\begin{array}{l}\text { Contamination areas and items labeled and proper decontamination } \\
\text { procedures used }\end{array}$ & 27 & 9.0 & 273 & 91.0 \\
\hline \multicolumn{5}{|l|}{ Cleaning } \\
\hline Clean department every shift & 44 & 69.8 & 19 & 30.2 \\
\hline Clean surface with antiseptic solution & 63 & 100.0 & 0 & 0.0 \\
\hline Follow standers of infection control & 63 & 100.0 & 0 & 0.0 \\
\hline
\end{tabular}

Is there relation between health team knowledge about radiation hazards and their practices? Table $(7,8)$.

Table (7): Relationship Between Total Score of Studied Sample knowledge About Radiation Hazards and | at Assuit University Hospitals 2015 ( $\mathbf{N}=\mathbf{3 0 0}$ ).

\begin{tabular}{|c|c|c|c|c|c|c|c|}
\hline \multirow{3}{*}{ Variables } & \multicolumn{6}{|c|}{ Level of performance } & \multirow{3}{*}{ P-value } \\
\hline & \multicolumn{2}{|c|}{ Poor $(n=114)$} & \multicolumn{2}{|c|}{ Fair $(n=157)$} & \multicolumn{2}{|c|}{ Good $(n=29)$} & \\
\hline & No. & $\%$ & No. & $\%$ & No. & $\%$ & \\
\hline \multicolumn{7}{|l|}{ Department } & \multirow{3}{*}{$0.016^{*}$} \\
\hline Diagnostic Radiation & 76 & 66.7 & 108 & 68.8 & 12 & 41.4 & \\
\hline Nuclear Medicine and Oncology Unit & 38 & 33.3 & 49 & 31.2 & 17 & 58.6 & \\
\hline \multicolumn{7}{|l|}{ Age: (years) } & \multirow{2}{*}{0.341} \\
\hline$<30$ & 44 & 38.6 & 49 & 31.2 & 14 & 48.3 & \\
\hline
\end{tabular}




\begin{tabular}{|c|c|c|c|c|c|c|c|}
\hline \multirow{3}{*}{ Variables } & \multicolumn{6}{|c|}{ Level of performance } & \multirow{5}{*}{ P-value } \\
\hline & \multicolumn{2}{|c|}{ Poor $(n=114)$} & \multicolumn{2}{|c|}{ Fair $(n=157)$} & \multicolumn{2}{|c|}{ Good $(n=29)$} & \\
\hline & No. & $\%$ & No. & $\%$ & No. & $\%$ & \\
\hline $30-40$ & 47 & 41.2 & 66 & 42.0 & 9 & 31.0 & \\
\hline$>40$ & 23 & 20.2 & 42 & 26.8 & 6 & 20.7 & \\
\hline \multicolumn{7}{|l|}{ Sex } & \multirow{3}{*}{$0.013^{*}$} \\
\hline Male & 76 & 66.7 & 114 & 72.6 & 13 & 44.8 & \\
\hline Female & 38 & 33.3 & 43 & 27.4 & 16 & 55.2 & \\
\hline \multicolumn{7}{|l|}{ Level of education } & \multirow{7}{*}{$0.000^{*}$} \\
\hline Illiterate & 14 & 12.3 & 6 & 3.8 & 0 & 0.0 & \\
\hline Basic education & 27 & 23.7 & 15 & 9.6 & 0 & 0.0 & \\
\hline Secondary & 13 & 11.4 & 22 & 14.0 & 8 & 27.6 & \\
\hline Technical Institute & 10 & 8.8 & 102 & 65.0 & 14 & 48.3 & \\
\hline University & 25 & 21.9 & 4 & 2.5 & 2 & 6.9 & \\
\hline Post graduate & 9 & 7.9 & 18 & 11.5 & 11 & 37.9 & \\
\hline \multicolumn{7}{|l|}{ Occupation } & \multirow{6}{*}{$0.000 *$} \\
\hline Radiologist & 28 & 24.6 & 2 & 1.3 & 2 & 6.9 & \\
\hline Oncologist & 20 & 17.5 & 10 & 6.4 & 4 & 13.8 & \\
\hline Nurse & 14 & 12.3 & 22 & 14.0 & 9 & 31.0 & \\
\hline Technician & 10 & 8.8 & 102 & 65.0 & 14 & 48.3 & \\
\hline Cleaner & 42 & 36.8 & 21 & 13.4 & 0 & 0.0 & \\
\hline \multicolumn{7}{|c|}{ Attending training courses about radiation therapy } & \multirow{3}{*}{$0.000 *$} \\
\hline Yes & 2 & 1.8 & 12 & 7.6 & 9 & 31.0 & \\
\hline No & 112 & 98.2 & 145 & 92.4 & 20 & 69.0 & \\
\hline
\end{tabular}

Table (8): Relationship Between Total Score of Studied Sample Practices About Radiation Safety Measures and their Personal Characteristics at Assuit University Hospitals 2015 ( $\mathbf{N}=300)$.

\begin{tabular}{|c|c|c|c|c|c|c|c|}
\hline \multirow{3}{*}{ Variables } & \multicolumn{6}{|c|}{ Level of performance } & \multirow{3}{*}{ P-value } \\
\hline & \multicolumn{2}{|c|}{ Poor $(n=114)$} & \multicolumn{2}{|c|}{ Fair $(n=157)$} & \multicolumn{2}{|c|}{ Good $(n=29)$} & \\
\hline & No. & $\%$ & No. & $\%$ & No. & $\%$ & \\
\hline \multicolumn{7}{|l|}{ Department } & \multirow{3}{*}{$0.016^{*}$} \\
\hline Diagnostic Radiation & 76 & 66.7 & 108 & 68.8 & 12 & 41.4 & \\
\hline Nuclear Medicine and Oncology Unit & 38 & 33.3 & 49 & 31.2 & 17 & 58.6 & \\
\hline \multicolumn{7}{|l|}{ Age: (years) } & \multirow{4}{*}{0.341} \\
\hline$<30$ & 44 & 38.6 & 49 & 31.2 & 14 & 48.3 & \\
\hline $30-40$ & 47 & 41.2 & 66 & 42.0 & 9 & 31.0 & \\
\hline$>40$ & 23 & 20.2 & 42 & 26.8 & 6 & 20.7 & \\
\hline \multicolumn{7}{|l|}{ Sex } & \multirow{3}{*}{$0.013^{*}$} \\
\hline Male & 76 & 66.7 & 114 & 72.6 & 13 & 44.8 & \\
\hline Female & 38 & 33.3 & 43 & 27.4 & 16 & 55.2 & \\
\hline \multicolumn{7}{|l|}{ Level of education } & \multirow{7}{*}{$0.000 *$} \\
\hline Illiterate & 14 & 12.3 & 6 & 3.8 & 0 & 0.0 & \\
\hline Basic education & 27 & 23.7 & 15 & 9.6 & 0 & 0.0 & \\
\hline Secondary & 13 & 11.4 & 22 & 14.0 & 8 & 27.6 & \\
\hline Technical Institute & 10 & 8.8 & 102 & 65.0 & 14 & 48.3 & \\
\hline University & 25 & 21.9 & 4 & 2.5 & 2 & 6.9 & \\
\hline Post graduate & 9 & 7.9 & 18 & 11.5 & 11 & 37.9 & \\
\hline \multicolumn{7}{|l|}{ Occupation } & \multirow{4}{*}{$0.000^{*}$} \\
\hline Radiologist & 28 & 24.6 & 2 & 1.3 & 2 & 6.9 & \\
\hline Oncologist & 20 & 17.5 & 10 & 6.4 & 4 & 13.8 & \\
\hline Nurse & 14 & 12.3 & 22 & 14.0 & 9 & 31.0 & \\
\hline
\end{tabular}




\begin{tabular}{|c|c|c|c|c|c|c|c|}
\hline \multirow{3}{*}{ Variables } & \multicolumn{6}{|c|}{ Level of performance } & \multirow{5}{*}{ P-value } \\
\hline & \multicolumn{2}{|c|}{ Poor $(n=114)$} & \multicolumn{2}{|c|}{ Fair $(n=157)$} & \multicolumn{2}{|c|}{ Good $(n=29)$} & \\
\hline & No. & $\%$ & No. & $\%$ & No. & $\%$ & \\
\hline Technician & 10 & 8.8 & 102 & 65.0 & 14 & 48.3 & \\
\hline Cleaner & 42 & 36.8 & 21 & 13.4 & 0 & 0.0 & \\
\hline \multicolumn{7}{|c|}{ Attending training courses about radiation therapy } & \multirow{3}{*}{$0.000^{*}$} \\
\hline Yes & 2 & 1.8 & 12 & 7.6 & 9 & 31.0 & \\
\hline No & 112 & 98.2 & 145 & 92.4 & 20 & 69.0 & \\
\hline
\end{tabular}

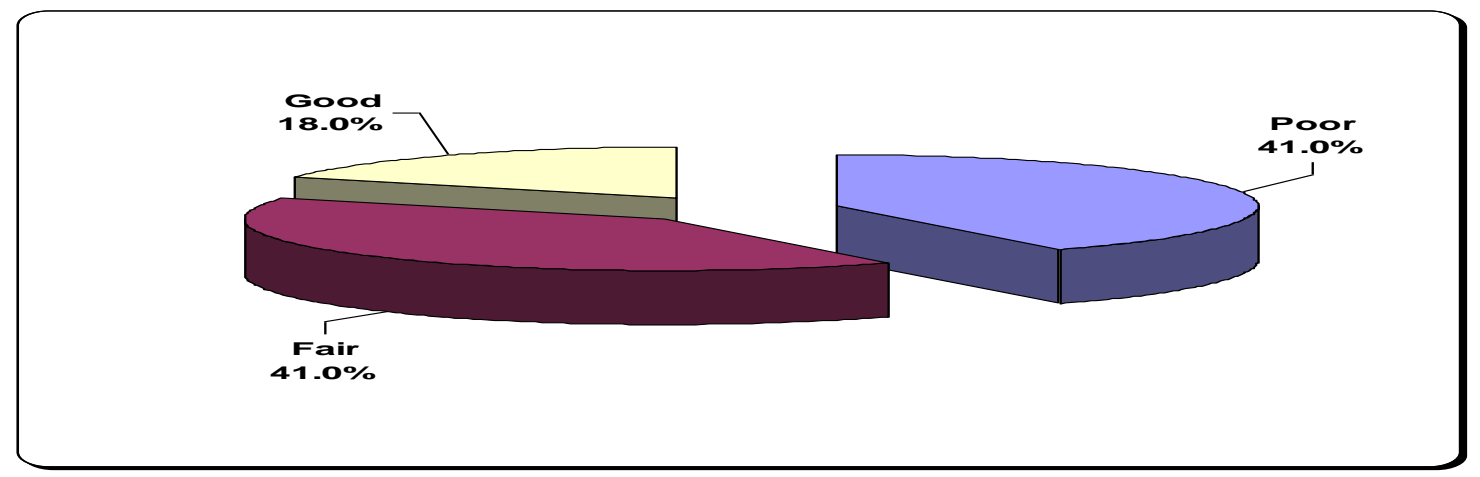

Fig. (1): Distribution of Studied Sample Regarding Their Total Score Of Knowledge About Radiation Hazards at Assuit University Hospitals 2015 (N=300)

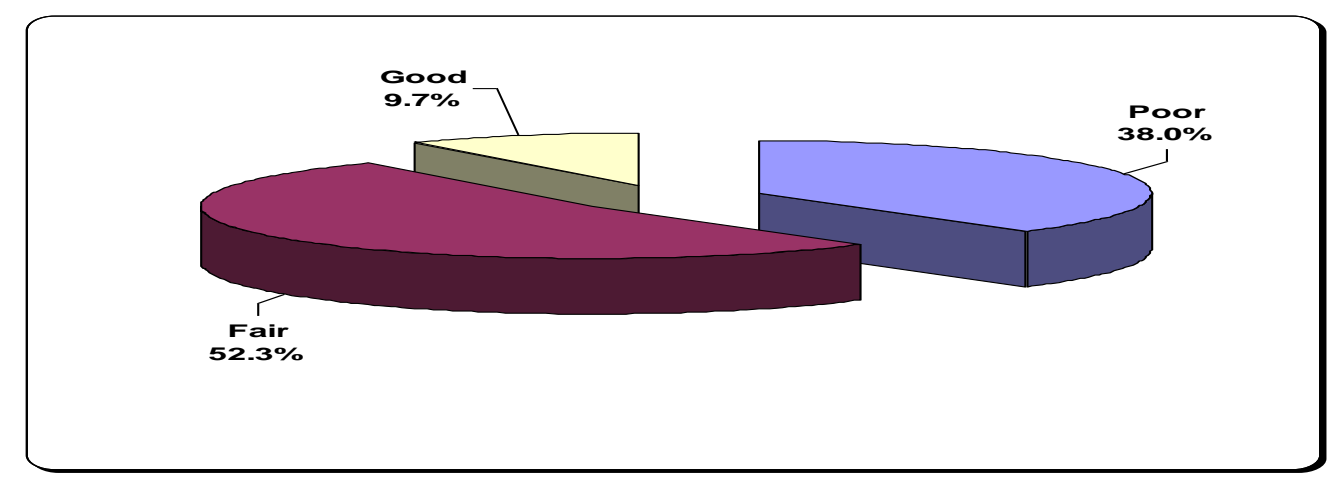

Fig. (2): Distribution of Studied Sample Regarding Their Practices Score About Radiation Safety Practice at Assuit University Hospitals 2015.(N=300)

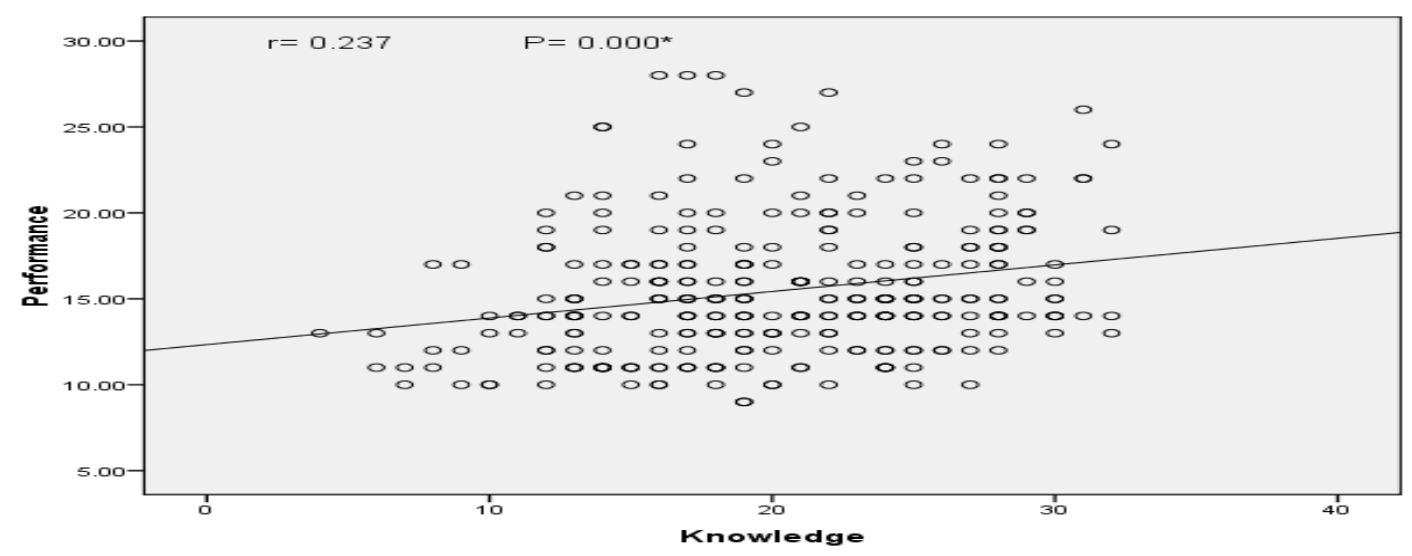

Fig. (3): Correlation Between Total Scores of Knowledge And Total Score Of Practice Among the Studied Sample Regarding Radiation Safety Measures at Assuit University Hospitals 2015. 
Table (1): Distribution of the studied sample regarding to their socio demographic characteristics. Regarding their age it was noticed that $40.7 \%$ of the workers aged between 30-40 years followed by $35.7 \%$ aged $<30$ years. Regarding marital status it was observed that $72.0 \%$ were married and $42.0 \%$ of the studied workers had technical institute. While only $6.7 \%$ were illiterate.

Table (2): Shows distribution of the studied sample according to their working condition at Assuit university hospitals. It was noticed that $65.3 \%$ of study sample were working at diagnostic radiation and $34.7 \%$ of them were working at nuclear medicine and oncology unit. Concerning occupation, $42.0 \%$ of study sample was technician followed by $21.0 \%$ were cleaners and $15.0 \%$ were nurses. $31.7 \%$ had job experience less than 5years and $18.0 \%$ of them had job experience less than 15 years.

Table (3). Illustrates that knowledge of the studied sample about radiation. It revealed that $22.3 \%$ of studied sample defined radiation correctly. While $25.0 \%$ of them had right knowledge about the causes of radiation pollution. $47.7 \%$ of them had right knowledge about symptom resulting from an over exposure to radiation

Table (4): It reveals that $71.7 \%$ of studied sample had right knowledge about the mechanism of radiation therapy. $57.0 \%$ of them had known the effect of radiation therapy on cancer and health cells. $70.0 \%$ of them mention types of radiation therapy. While $63.0 \%$ had knowledge about special precautions of radiation therapy.

Table (5): Illustrates knowledge of the studied sample regarding safety measures. $91.7 \%$ of studied sample mention the importance of safety tools correctly (Protected from exposure to radiation). It was observed that $68.0 \%$ of the studied sample reported gloves and suitable shoes for safety tools of health team, while about $2.3 \%$ of them reported head cap. Also $75.3 \%$ of studied sample said safety precaution for the unit of radiation was present. The results also revealed that $84.5 \%$ of the studied sample stated that was lead walls and glass for safety characteristics of radiation unit, while about $1.8 \%$, $0.9 \%$ stated that complete emergency equipment and special containers for keeping radioactive materials.

Table (6): Reveals the distribution of the studied sample according to radiation safety practice. It was observed that $53.0 \%$ of the studied sample were wearing gloves at all time $.7 .3 \%$ of them having personal monitoring badages. And $2.5 \%$ of them wearing head cap that they mentioned it was not enough in the unit. While $73.7 \%$ were made safe work practice adapted to make appropriate use of time. It was noticed that only $7.3 \%$ of the sample were given radiation safety training .Although $98.3 \%$ of them were given patient instructions before and after producers. Concerning to radiation warning signs and caution signs grinding equipment observed that $99.7 \%$ of studied sample displayed at the door. Regarding the cleaning it was observed that $69.8 \%$ of cleaner was cleaned department every shift and all of them used antiseptic solution and follow standers of infection control.

Table (7): Represents relationship between total score of studied sample knowledge about radiation hazards and their personal characteristics. This table shows that there was statistical significant difference were found between studied sample level of education, occupation and their total score of knowledge about radiation hazard. P. value (0.000and $0.000)$ respectively.

Table (8): Reveals that Relationship between total score of studied sample practices about radiation safety measures and their personal characteristics at Assuit university hospitals. This table shows that there were statistical significant difference were found between studied sample department, sex ,level of education, occupation and attending training courses and their total score of studied sample practices about radiation safety measures. P. value $(0.016,0.013,0.000,0.000$ and 0.000$)$ respectively.

Fig. (1): Distribution of studied sample regarding their total score of knowledge about radiation hazards at Assuit university hospitals2015. (N=300)

Fig. (2): Show distribution of studied sample regarding their practices score about radiation safety practices at Assuit university hospitals 2015. ( $\mathrm{N}=300)$ Fig.(3): Illustrates that correlation between total scores of knowledge and total score of practices among the studied sample regarding to radiation safety measures . There was a positive correlation between total score of studied studied sample knowledge and total score of studied sample practices regarding radiation safety measures with high statistically significant difference $(r=0.237 ; \mathrm{p}$ $=0.000)$.

\section{Discussion}

Radiation is a threat to health in work place and in general environment, the extent of danger depends on the dose and type of radiation. Prolonged exposure to radiation can cause skin ulcers, damage to cells, cancer, premature aging, and kidney dysfunction, cataracts, and genetic disorders in the children of those cells have been damaged (Gawenda, 2008).

The findings of the present study regarding to studied sample socio demographic characteristics and work condition revealed that more than one third of them were females .This is congruent with (Alex, 2006) who study high radiation exposure among female 
radiologist and reported that there were significantly higher proportion of female off spring.

The findings of the present study showed that the range of the studied sample age more than two fifth were (30-40) year's old this age composition of workforce affects its health status as younger employees may be at increased risk of hazards due to limited job training and skills. This findings agreed with (Ebrahim et al., 2011) who study compliance to safety measures toward radiation hazards among heath.

Concerning studied sample educational level, the finding of the current study indicated that less than half were secondary level of education which was expected as technical workers .This findings agree with the report of (Central Agency for Public Mobilization \& statistics 2009) about work hazards in Egypt revealed that majority of workers to be risk had secondary or technical level of education.

Regarding to years of experience at work in radiation therapy at the present study show that nearly one third of studied sample had 5 years of experience it was proved that young workers had higher risk due to different reasons such as having less experience, less training, curiosity risk taking. This results disagreed with (Rahman, 2008) who found that less than half of the studied sample had years of experience from (7-10) years.

Concerning studied sample knowledge about types of radiation therapy, time of radiation session, parts of body affected by radiation, the most affected age of radiation exposure, and importance of safety measure corresponding to nurses and clerk had un satisfactory awareness about radiation therapy. This congruent with (Quhnin et al., 2007) who study knowledge and practice of radiation safety among non radiologist and found $22 \%$ of non-radiologist (nurses and clerk) had satisfactory knowledge about effect of radiation on the body system. This attributed to low education and they are not interested in improving their knowledge

As regard to studied sample knowledge about safety measures in radiation unit the findings of the present study revealed that the majority of studied sample had fair knowledge about safety measures. This was accordance with (Quhnin et al., 2007) who reported that the majority of studied sample didn't receive adequate radiation protection teaching.

Radiation safety training at radiation department takes a different approach than the traditional methods and topics used at other facilities, where the more routine radiation users focused on standard of training topics of contamination control, area survey, and time, distance, and shielding, radiation safety measure must be centered on preventing accidents and hazards ( Rothmore, 2008) .
In relation to PPE compliance in the present study was observed that more than half of health team was wearing gloves, less than quarter of them wearing mask, and $7.3 \%$ wearing monitor devices that causes of non compliance by insufficient or uncomfortable wearing of personal protective equipment. .This was accordance with (Pak, 2008) who found that less than one third of health team used radiation protective measures such as eye glasses and lead aprons, only $7 \%$ regularly utilized dose badge to monitor the exposure.

Robinson \& Grainger, (2006) who reported that the triad of radiation protection actions comprise of 'time- distance- shielding reduction of exposure time, increasing distance from source, and shielding of patients and occupational workers have proven to great importance in protecting patient, personnel, and members of the potential risk of radiation. Poster and signs and periodical check up to work environment .This congruent with (Wai, 2009) who study in medical surveillance for radiation workers and the role of occupational physician and stated that the $82 \%$ of the workers had safety training course during the work.

In this study regarding to safe work procedures compliance it was observed that $58.0 \%$ and $71.0 \%$ of studied sample complained with safe shielding, and safe distance, $44.0 \%$ of them regularly hand washing, and $73.7 \%$ were complained with safe time this explained to a weariness of radiation polices . This contradicted with (Reagan , 2010) who study factors related to radiation safety practice in California and found compliance of employee to radiation safety practice were $77.1 \%$ compliance to safety practice and $70.5 \%$ compliance with personal safety measures.

In relation to work site safety measures policies the result of present study revealed that majority of studied sample had not attending training course about radiation safety they compliance by safety waste disposal, poster and signs and periodical check In present study there were significant statistical differences between knowledge and personal characteristic this explained that age, years of experience, level of education and job training that all increasing awareness about radiation hazards. These findings agree with (Wucher\& Loose 2009) who study occupational exposure to radiation and found significant relation between the knowledge and the socio demographic characteristics. Also agree with (Sheyn et al.,2008) in their research about efficacy of radiation safety education initiative in reducing radiation exposure.

This result indicated that a positive association between education and safety awareness. High educated workers recorded the best awareness on 
safety they indicated the highest level of job satisfaction were the most compliance with safety procedure and the most awareness to radiation hazards.

In the present study there were significant statistical differences between studied sample performance and their type of occupation. Regarding radiation safety measures the radiographer (Technician) had best level of performance than the rest of studied sample members due to specialization of them. This was agree with the findings of (Rothmore, 2008) who was found that radiographer had a highest level of performance of the staff about radiation safety measures.

In present study found that there was significance statistical difference in relation between studied sample gender and their performance. That the females had best performance than males due to their follow the instructions and they afraid from infertility. This contradict with (Niklson et al, 2006) who study the avoidance of radiation injures from medical interaction procedures; they found that there were no relation between compliance and gender.

In the present study it was observed that there was a significant statistical difference in relation between studied sample education level and their practices of safety measures $\mathrm{p}$ value $=0.000$. Also there was a significant statistical difference in relation between studied sample practices and there experience it means that more years of experience lead to best level of performance .This result agree with (Reagan, 2010) who found that years of employment in radiological were significantly to adherence with safety practices.

This study finding that there were significant statistical differences between studied sample knowledge and their performance. This attributed that more knowledge of radiation hazards lead to more compliance.

\section{Conclusion}

The study concluded that less than half of the studied sample $(41 \%)$ having poor knowledge regarding radiation hazards. There was statistical significant difference were found between studied sample work place, level of education, occupation and years of experience and their total score of knowledge about radiation hazard $P$. value $(0.029,0.000$, 0.000 and0.005) respectively. More than half of them having satisfactory practice. Also there were statistical significant difference were found between studied sample department, sex ,level of education , occupation, years of experience and attending training courses and their total score of studied sample practices $P$. value $(0.016,0.013,0.000$, $0.000,0.000$ and 0.000$)$ respectively .

There was a significant difference was found between score of knowledge and practice. There was a positive correlation between knowledge and practice of the studied sample regarding radiation safety measures

\section{Recommendations}

Based on the previous findings of the present study, the following recommendations are suggested

- The hospitals must be provide radiation departments with adequate personal protective equipment to reduce exposure of the studied sample from radiation hazards.

- Develop a plans for periodical safety measures training courses and educational programs for the studied sample member in radiation setting to help in improving their practice and update their knowledge.

\section{References}

1. AbdElzaher, O., Qayed, M., Mohamed, S., \& Mohamed, A., (2014): Farmer's knowledge, attitude and practice about pesticides in a village of Abnub district, Assiut Governorate. Thesis Master Degree in Community Health Nursing at Faculty of Nursing, Assiut University.

2. Alex, M., (2006): High radiation exposure among female radiologist, $2^{\text {nd }}$ ed , USA, pp 245-256.

3. Amirzadeh, F., (2007): Survey of radiation protection awareness among radiation workers in Sheraze hospital, India, Turns E Journals Vol. 13, No.8. pp.38-43

4. Cardis, E., Vrijheid, M., Blettner, M., Gilbert, M., Hakama, M., Hill, C., Howe, G., Kaldor, J., \& Muirhead, R., (2007): The 15-Country Collaborative Study of Cancer Risk among Radiation Workers in the Nuclear Industry: Estimates of Radiation-Related Cancer Official journal of the Radiation Research Society Risks. Vol.167. No. 4, pp. 396-416.

5. Central Agency for public Mobilization and statistic (CAPMS) report (2009): Annual report of occupational hazards in Egypt.

6. Ebrahim, N., Elbeih, A., \& Guirguis, S., (2011): Compliance To Safety Measures Toward Radiation Hazards Among The heath team. Thesis master degree community health nursing at Faculty of Nursing Ain Shams University . 
7. Gates, R., Fink, R., \& Scheetz, L., (2008): Oncology Nursing secrets, $3^{\text {rd }}$ ed , Mosby London. USA. pp. 43-51.

8. Gawenda, D., (2008): Occupational Health Nursing care guidelines, $2^{\text {nd }}$ ed Springer Company London, pp 233

9. Heaney, M., (2010): Radiation workers at higher risk for developing melody plastic syndrome, $3^{\text {rd }}$ ed , black well, India, pp. 305-317.

10. Mohammed, Zayat, H., EzzEl_dine, A.,andKhalil, M., (2012): Immunological effects of ionizing radiation among health care providers in clinical oncology and nuclear medicine department. Thesis master degree Community Medicine at Faculty of Medicine Assuit University.

11. Mojiri, M., \& Moghimbeigi, A., (2011): Awareness and attitude of radiographers towards radiation protection, Journal of Paramedical Sciences Vol.2, No.4.pp22-24

12. Niklson, S., Piyils, Z., \& Tanhaken, R., (2006): Avoidance of radiation injures from medical interaction procedures, $8^{\text {th }}$ ed hilophidia lippincall, Witti and Wikins pp .127.

13. Pak, T., (2008): knowledge and practice of radiation safety among non-cardiologist, American journal of cardiology, Vol.15 No.2.pp 126- 128.

14. Quhnin, T., Taylor, C., \& Sabharwal, T., (2007): knowledge and practice of radiation safety amng non radiologist by Mcgill $\mathrm{J}$ med, Vol. 9. No.2. pp.54-58

15. Radiation Protection Guidance (2010): For Hospital Staff Prepared for Stanford Hospital and Clinics,Lucile Packard Children's Hospital And Veterans Affairs Palo Alto Health Care System.

16. Rahman, D., (2008): Knowledge and practice of radiation safety among invisible cardiologist, UAS JPMA .Vol.58. No.3, pp119122.

17. Reagan, J., (2010): Factors related to radiation safety practice in California, Radiology technology. Vol .81.No.6.pp 538-547.

18. Robinson, S., \& Grainger, L., (2006): The trial of radiation protection actions comprise of time distance shielding, USA, Journal of Radiology. Vol .6.No.4. pp 149-152.

19. Rothmore, L., (2008): lead aprons, radiographers and discomfort: a pilot study. USA, Journal of radiology .Vol .4. No7.pp. 4552.

20. Sheyn, D., Racadio, J., Ying, J., \& Jonsofle, N., (2008): University of Cincinnati College of medicine, OH. USA, HA522-(319) 315-414. Available http//www.ncbinin.gov/pubmed
21. Smith, F., (2013): Community public health nursing practice, health for families and population, $5^{\text {th }}$ ed Elsevier Sounders, pp.251-252

22. Wai, T., (2009): Medical surveillance for radiation workers and the role of occupational physician, $2^{\text {nd }}$ ed. Mesby, USA, PP.112- 119.

23. Wiley, J., (2008): Occupational Health Nursing Care guidelines, $3^{\text {rd }} \mathrm{ed}$, Springer Company London, pp159.

24. World Health Origination (WHO ( $_{\text {a }}$ (2014): Radiation, ionizing; http//who.int./topics/radiation_ionizing

25. World Health Origination $\left(\mathrm{WHO}_{\mathrm{b}}\right)$ (2014): Radiation, non_ionizing; http//who.int./topics/radiation _ non_ionizing.

26. Wucher, M., \& Loose, R., (2009): Occupational Exposure to Radiation. Radiology. Vol .45. No. 3. pp 291-302 quiz 303. 